2. Chakos A, Ferret P, Muston B, Yan TD, Tian DH. Ex-vivo lung perfusion versus standard protocol lung transplantation-mid-term survival and meta-analysis. Ann Cardiothorac Surg. 2020;9:1-9.

3. Gloria JN, Yerxa J, Kesseli SJ, Davis RP, Samoylova ML, Barbas AS, et al. Subnormothermic ex vivo lung perfusion attenuates graft inflammation in a rat transplant model. J Thorac Cardiovasc Surg. 2022; 164:e59-70.
4. Nakajima D, Chen F, Yamada T, Sakamoto J, Osumi A, Fujinaga T, et al. Hypothermic machine perfusion ameliorates ischemia-reperfusion injury in rat lungs from non-heart-beating donors. Transplantation. 2011;92:858-63.

5. Hashimoto K, Cypel M, Juvet S, Saito T, Zamel R, Machuca TN, et al. Higher M30 and high mobility group box 1 protein levels in ex vivo lung perfusate are associated with primary graft dysfunction after human lung transplantation. $J$ Heart Lung Transplant. 2017;17:1870-3.
See Article page e59.

\section{Commentary: Colder may be better in ex vivo lung preservation}

\author{
Stephanie H. Chang, MD
}

Ex vivo lung perfusion (EVLP) has emerged over the last decade as a method of expanding the donor pool for lung transplantation. ${ }^{1}$ The current clinical use of EVLP occurs with normothermic perfusion of the donor allograft, which has resulted in similar short-term ${ }^{1}$ and long-term ${ }^{2}$ outcomes compared with non-EVLP lung transplants. However, other solid organs have used hypothermic machine perfusion with good outcomes, ${ }^{3}$ leading to a current clinical trial to determine whether normothermic or hypothermic machine perfusion results in improved outcomes for liver transplantation.

To determine whether subnormothermic perfusion for EVLP can be beneficial, the authors used a rat model to evaluate damage-associated molecular patterns (DAMPs) at different temperatures while on EVLP. ${ }^{4}$ Clinical studies have previously demonstrated that increased ischemiareperfusion injury, as measured by increased cell death signals, in EVLP perfusate has been associated with grade 3 primary graft dysfunction (PGD), as well as higher mortality. ${ }^{5}$ Thus, the authors evaluated cell death signals and DAMPs in the perfusate at normothermic $\left(37^{\circ} \mathrm{C}\right)$ and subnormothermic $\left(30^{\circ} \mathrm{C}\right.$ and $\left.25^{\circ} \mathrm{C}\right)$ temperatures. The $25^{\circ} \mathrm{C}$ EVLP was associated with a lower increase in certain

From the Department of Cardiothoracic Surgery, New York University Langone Health, New York, NY.

Disclosures: The author reported no conflicts of interest.

The Journal policy requires editors and reviewers to disclose conflicts of interest and to decline handling or reviewing manuscripts for which they may have a conflict of interest. The editors and reviewers of this article have no conflicts of interest.

Received for publication Feb 1, 2021; revisions received Feb 1, 2021; accepted for publication Feb 3, 2021; available ahead of print Feb 9, 2021.

Address for reprints: Stephanie H. Chang, MD, Division of Thoracic Surgery, Department of Cardiothoracic Surgery, New York University Langone Health, 530 First Ave, Suite 9V, New York, NY 10016 (E-mail: stephanie.chang@nyulangone.org). J Thorac Cardiovasc Surg 2022;164:e72-3

$0022-5223 / \$ 36.00$

Copyright (C) 2021 by The American Association for Thoracic Surgery

https://doi.org/10.1016/j.jtcvs.2021.02.006
Check for updates

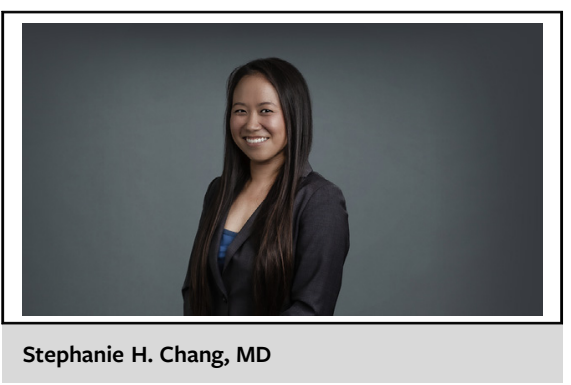

CENTRAL MESSAGE

Ex vivo lung perfusion (EVLP) at

$25^{\circ} \mathrm{C}$ appears to be associated

with decreased histologic injury

and cell death signals compared

to normothermic EVLP in an

animal model. Further studies are

needed to evaluate clinical

efficacy.

cytokines and DAMPs compared with normothermic EVLP, suggesting decreased inflammation with subnormothermic EVLP. Transplanted lungs from the 3 EVLP groups $\left(37^{\circ} \mathrm{C}, 30^{\circ} \mathrm{C}\right.$, and $\left.25^{\circ} \mathrm{C}\right)$ and from static cold storage (SCS) were also compared at 2 hours posttransplantation. Although there was no significant difference in the ratio of arterial oxygen concentration to the fraction of inspired oxygen $(\mathrm{P} / \mathrm{F}$ ratio), there was a greater histologic injury in the $37^{\circ} \mathrm{C}$ and $30^{\circ} \mathrm{C}$ groups compared with SCS, with no difference between $25^{\circ} \mathrm{C}$ and SCS. Although this rat model demonstrates the potential decreased inflammation and posttransplantation graft injury in subnormothermic EVLP, the posttransplantation measurement of DAMPs and cytokines still favor SCS even over subnormothermic EVLP.

The results from this article are overall promising in demonstrating possible decreased injury in subnormothermic EVLP. However, there are additional models that 
should be assessed. The posttransplantation $\mathrm{P} / \mathrm{F}$ ratio and histologic injury were assessed only at 2 hours posttransplantation, whereas primary graft dysfunction presents within 72 hours after transplantation and often progresses over this time period. Use of a longer posttransplantation rat model would further elucidate the different effects of normothermic EVLP, subnormothermic EVLP, and SCS. Additional work in large animal models also may help determine the efficacy of subnormothermic EVLP. Overall, this study suggests that perhaps $25^{\circ} \mathrm{C}$ perfusate in EVLP may result in less inflammation compared with normothermic EVLP, laying the groundwork for future studies with potential clinical applications.

\section{References}

1. Cypel M, Yeung JC, Liu M, Anraku M, Chen F, Karolak W, et al. Normothermic ex vivo lung perfusion in clinical lung transplantation. $N$ Engl J Med. 2011;364: 1431-40.

2. Divithotawela C, Cypel M, Martinu T, Singer LG, Binnie M, Chow CW, et al Long-term outcomes of lung transplant with ex vivo lung perfusion. JAMA Surg. 2019;154:1143-50.

3. Guarrera JV, Henry SD, Samstein B, Odeh-Ramadan R, Kinkhabwala M Goldstein MJ, et al. Hypothermic machine preservation in human liver transplantation: the first clinical series. Am J Transplant. 2010;10:372-81.

4. Gloria JN, Yerxa J, Kesseli SJ, Davis RP, Samoylova ML, Barbas AS, et al. Subnormothermic ex vivo lung perfusion attenuates graft inflammation in a rat transplant model. J Thorac Cardiovasc Surg. 2022;164:e59-70.

5. Hashimoto K, Cypel M, Juvet S, Saito T, Zamel R, Machuca TN, et al. Higher M30 and high mobility box 1 protein levels in ex vivo lung perfusate are associated with primary graft dysfunction after human lung transplantation. J Heart Lung Transplant. 2018;37:240-9. 